\title{
WHAT ABOUT THE INTERIOR CASTLE? \\ RESPONSE TO IENCA'S AND ANDORNO'S NEW HUMAN RIGHTS IN THE AGE OF NEUROSCIENCE AND NEUROTECHNOLOGY
}

\begin{abstract}
A b s t r a c t. Ienca's and Andorno's propositions of three new human rights presented in the article "Towards new human rights in the age of neuroscience and neurotechnology" prima facie seems very attractive and adequate to nowadays dangerous for human freedom. But there are still a few very serious doubts. The first of them is very general and we can express it in the question: is there a possibility to reconcile the philosophy neuroscience/neurotechnology and the related with them way of thinking about the individual, with the philosophy of human rights? The second is more specific but strictly connected with the first one: how do we reconcile the technological infiltration into our interior castle - the brain and its associated mind - with the freedom of thought, conscience, and religion, not only as our individual essence but also as part of the foundation of a democratic state ruled by law?

In the article presented above I've tried to show the inadequacy of both systems, especially inherently associated with them visions of human being.
\end{abstract}

Key words: cognitive liberty; freedom of thought; freedom of conscientious; neuroscience; philosophy of human rights.

\section{INTRODUCTION}

The tumultuous development of science and technology, which we are witnessing, is undoubtedly one of the most characteristic features of modernity. Icons that symbolize everyday revolutions that successively change our

Dr hab. OKTAWIAn NAwrot, prof. nadzw. UG - Katedra Teorii i Filozofii Państwa i Prawa, Sędzia Sądu Najwyższego; adres do korespondencji: ul. Jana Bażyńskiego 6, 80-309 Gdańsk; e-mail: nawrot@ug.edu.pl

Prof. OKTAWIAN NAWROT - Department of Theory and Philosophy of Law and State Faculty of Law and Administration University of Gdansk; address for correspondence - e-mail: nawrot@ug.edu.pl; o.nawrot@gmail.com 
view of reality - the cute visage of Dolly the sheep, strings of numbers representing the world-wide web and virtual reality, smartphones, brain-computer interfaces (BCIs), miniature chips, nanopills, etc. - have stormed into our consciousness, becoming a natural part of reality. It would be a truism to say that taking away electronic gadgets from modern representatives of the technologically advanced part of the world would probably lead to that part of the world feeling lost and certainly as if it lost important reference points enabling self-identification and smooth functioning. Science and technology have taken root in our world and even in us. First we learned about it, now it learns about us. The devices we use every day, like the smartphone mentioned above, often "know" us better than our loved ones. They "know" our interests, desires, habits, monitor our physical activity, monitor our progress, help manage our finances, provide us with entertainment, motivate us, suggest what choice to make, participate in decision-making. They live with us in perfect symbiosis, like the bacteria living inside our bodies enabling proper functioning. Without going into an assessment of this state of affairs, since that is not the purpose of this paper, I will allow myself to consider it a fact that is not subject to discussion in principle.

The next step on the path of permeation of the biological with the technological is neurotechnology, which was described by Marcello Ienca and Roberto Andorno in the article "Towards new human rights in the age of neuroscience and neurotechnology" (2017). Not only did the authors present the latest achievements of neuroscience as well as the breakthroughs that are likely to occur in the near future, but they also suggested responses to the occurring advances, writing them into the frames of the human rights protection systems. In particular, they developed three extremely intriguing new human rights: 1 . the right to mental privacy, 2. the right to mental integrity, 3. the right to psychological continuity. By agreeing in principle with the possibility of deriving these rights from the already existing human rights catalog, I would like to draw attention to one - in my view - basic issue and related doubts. Namely, how do we reconcile the already clearly visible on the horizon, and perhaps desirable to many, technological infiltration into our interior castle - the brain and its associated mind - with the freedom of thought, conscience, and religion, not only as our individual essence but also as part of the foundation of a democratic state ruled by law?

This article examines the possibility of reconciling neuroscience and neurotechnology, and the related with them way of thinking about the individual, with the philosophy of human rights, in which freedom of thought, conscience and religion play a key role. The article shows the inadequacy of 
both systems, implying the need to reject or radically reconstruct one of them - I am afraid that the system of human rights protection.

\section{PHILOSOPHY OF EMERGING TECHNOLOGIES VERSUS PHILOSOPHY OF HUMAN RIGHTS}

On May 4-5, 2015, at the Council of Europe headquarters in Strasbourg, the international conference "Emerging technologies and human rights" took place. The purpose of this event was to identify and discuss the dangers of science and technology, including neuroscience and neurotechnology, to human rights and then indicate the values and associated freedoms and rights that should be safeguarded.

Panelists drew attention to the fact that the process and consequences of the current technological convergence, in particular the convergence of nanotechnology, biotechnology, information technology, and cognitive science (NBIC convergence), are something completely different from the centuries of binding and mutual use of achievements in particular fields of science and technology. The reality that thanks to NBIC convergence is uncovered and the possibilities associated with it go beyond the goals set in traditional scientific disciplines and related technologies. Consequently, the problems that arise from this convergence diverge from the already complex problems caused by advances in biology and medicine. These problems arise in areas which, although they are still being created, have become an important part of our reality. These areas are "between" the traditionally understood realms of reality - humans and the surrounding world, biological life and artificial life, man and machine, intelligence and artificial intelligence, thought and information. It is impossible to assign them unequivocally to traditionally recognized areas of science, especially natural sciences. Biology and medicine, whose domain is the study of the living world, do not have enough tools to describe these phenomena; the instrument of physics, which focuses on understanding the inanimate world, is also inadequate. Biology is increasingly becoming technology, and technology biology.

In the report published over 15 years ago by the National Science Foundation (NSF) and the United States Department of Commerce titled "Converging Technologies for Improving Human Performance: Nanotechnology, Biotechnology, Information Technology and Cognitive Science" the authors indicated the following areas that NBIC convergence could particularly impact in the near future: expanding human cognition and communication, improving hu- 
man health and physical capabilities, enhancing group and societal outcomes, national security and unifying science and education (Roco, Bainbridge 2003, p. X-XI).

Going beyond the perspective of twenty years, the reports' authors predicted that NBIC convergence will have a significant effect on areas and phenomena such as: work efficiency, the human body and mind through the life cycle, communication and education, mental health, aeronautics and space flight, food and agriculture, sustainable and intelligent environments, selfpresentation and fashion, and transformation of civilization (Roco, Bainbridge 2003, p. X-XI; Bainbridge, Roco 2005).

Without describing the specific technologies that are currently being developed, and which are to be the cause of the impressive achievements mentioned above, including in particular neurotechnology, the underlying vision of man should be identified. All of these technologies are founded on the well-known purely biological philosophy, and even more so the mechanistic vision of man. As Thomas Hobbes and Descartes emphasized in the $17^{\text {th }}$ century, and later Julien Offray de la Mettrie even more emphatically, man can be described as any mechanism can be described. "Yet a clock constructed with wheels and weights observes all the laws of its nature just as closely when it is badly made and tells the wrong time as when it completely fulfils the wishes of the clockmaker. In the same way, I might consider the body of a man as a kind of machine..." (Descartes 1985, p. 58-59). From this perspective, a person is treated as a kind of mechanism, or as 1. neither better nor worse than other mechanisms - just slightly different; or as 2 . a mechanism of a particular, distinguished type that can be compared to other mechanisms within the type to which it was assigned.

Bringing man down to the level of the machine obviously brings with it serious doubts as to the possibility of reconciling the a priori model adopted in the "philosophy" of NBIC convergence with the vision of humans constituting the foundation of the human rights protection systems. Just as with every reductionism, the mechanistic approach takes away certain human qualities from the individual. In this case, the stakes are really high - the constitutive qualities of a human being perceived through the anthropologic framework as the foundation of the idea of a democratic state ruled by law, and thus the key values for that state. Thus the stakes are inherent human dignity, the identity and integrity of a human being, equality, and freedom. As previously mentioned, the mechanisms can function differently - to fulfill their goals or not. If the mechanism does not meet the assumed function, it can be repaired - if the repair costs are acceptable - or possibly modified or "with- 
drawn." Thus, there are better and worse mechanisms, efficient and not. Transferring this kind of thinking onto human beings can lead to their objectification, and consequently not only to the limitation or even deprivation of some of their freedoms and rights, but also to questioning their legal status.

In the context of a mechanistic understanding of humans, it should also be noted that NBIC convergence, with significant contribution from neurotechnology, revives the dreams of human improvement. Every mechanism (why not the human brain then?) can be redesigned, new features added, made more efficient; thus we could improve the perceptive capabilities of the individual, improve memory, improve and expand the ability to perform mental operations, etc.

Without developing the above thought further, let us remember that the foundation of the human rights systems created after World War II was the recognition of inherent human dignity, referring to, among others, our biological and mental (im)perfection. This phenomenon, which should be clearly emphasized, has not been incorporated into the form of law, which, in order to fulfill its functions, must be established by the appropriate public authorities. Dignity was deemed to be a primordial phenomenon, connected with the essence and existence of the individual, from which its basic rights and freedoms emanate. For example, in the first sentence of the Preamble to the Universal Declaration on Human Rights the following statement appears: "Whereas recognition of the inherent dignity and of the equal and inalienable rights of all members of the human family is the foundation of freedom, justice and peace in the world...". This dignity excludes the reduction of a human being to a certain plane of her existence - the biochemical or bioelectrical processes taking place within the framework of the body - and the differentiation and evaluation of individuals in view of these processes.

\section{ESSENTIAL HUMAN FREEDOMS}

On January 6, 1941, when the world plunged into the chaos of war, Franklin Delano Roosevelt delivered a message to the Congress outlining a vision of the world of the future, a world worth fighting for. This world, according to the president, should be based on four essential human freedoms: freedom of speech and expression, freedom of every person to worship God in his 
own way, freedom from want, and freedom from fear ${ }^{1}$. Adopting this vision after the end of the war, the United Nations ceremoniously proclaimed in the Universal Declaration on Human Rights, passed on December 10, 1948, that the highest goal of man is "the advent of a world in which human beings shall enjoy freedom of speech and belief and freedom from fear and want." Recognizing that the freedom of thought, conscience and religion play a key role in creating and sustaining a democratic society, article 18 of the Declaration confirmed that "everyone has the right to freedom of thought, conscience and religion."

The right to freedom of thought, conscience and religion expressed in the Universal Declaration on Human Rights includes (Nawrot 2015):

$1^{0}$ the major primary act - choice of beliefs (worldview, system of values, religion, etc.);

$2^{0}$ the minor primary act - modification of beliefs;

$3^{0}$ the secondary act - manifestation of beliefs.

In effect, the above-mentioned concept of freedom of thought, conscience and religion is the result of the authors of the Declaration accepting a particular anthropology - particularly, the axiological view of a human being. According to this vision, presented expressis verbis in article 1 of the Declaration, "all human beings are born free and equal in dignity and rights. They are endowed with reason and conscience and should act towards one another in a spirit of brotherhood." This vision was largely a response to the models on which two fundamental ideologies arose that rejected the system of values of the democratic state ruled by law: fascism and communism. Fascism negated human equality, among others. By referring to social Darwinism, fascists formulated the conclusion that as a result of biological evolution a division of the human species had taken place. Although built around the root "man," the terms "underman" (untermensch) and "overman" (übermensch) suggest that not only are we dealing with different races within the species, but also with different species. Their different, biologically conditioned, nature determines the place of the individual in the world, especially in society, predestining to certain functions.

Similarly, communists, who in accordance with the Manifesto of the Communist Party chose as their goal to abolish "eternal truths, $[\ldots]$ all religion,

\footnotetext{
${ }^{1}$ The full text of the address is available for example from Wikipedia - The Four Freedoms speech, http://en.wikisource.org/wiki/The_Four_Freedoms_speech.
} 
and all morality," ${ }^{2}$ because of their alleged destructive character towards human freedom, in fact negated both: freedom and human dignity. Each time those in power acquire the role of the "Great Moralizer," it inevitably leads to the taking away of individual freedoms of thought, conscience and religion, which ultimately results in enslavement and renders individuals thoughtless and passive instruments of totalitarian rule (Zdybicka 1998, p. 128). Thus, the individual is deprived of not only one of the elements rooted in his nature but worse loses his constitutive character. According to the classical definition formulated in the 6th century by Boethius, persona est naturae rationalis individua substantia, ipso facto the essence of man is rationality. This is not possible in situations when the individual is deprived of the ability to think and thereby act autonomously.

Consequently, the freedom of thought, conscience and religion recognized by the United Nations was to a large extent an opposition to the current of thought that dominated European, and wider world, thought about human beings for some time and "resulted in barbarous acts which have outraged the conscience of mankind" (Preamble to the Universal Declaration on Human Rights). This remark is worth emphasizing, as it contains an important guideline for the interpretation of provisions relating to individual freedoms, also in the context of the possible use of neurotechnology, as well as the essence of a democratic society and state.

The concept of freedom, thought, conscience and religion presented above was confirmed and developed by the International Covenant on Civil and Political Rights (ICCPR), which was opened for signing in New York on December 19, 1966. On the basis of article 18 (1) of the ICCPR: "Everyone shall have the right to freedom of thought, conscience and religion. This right shall include freedom to have or to adopt a religion or belief of his choice, and freedom, either individually or in community with others and in public or private, to manifest his religion or belief in worship, observance, practice and teaching." The treaty fully reaffirmed the right to freedom of thought, conscience and religion both within the scope of the above-mentioned major and minor primary acts as well as the secondary act. Moreover, in the General Commentary to article 18 of the ICCPR, the UN Human Rights Committee stated that the right to freedom of thought, conscience and religion is "far-reaching and profound" (CCPR/C/21/Rev.1/Add.4). This law encompasses

\footnotetext{
${ }^{2}$ Manifesto of the Communist Party by Karl Marx and Frederick Engels February 1848, online version: https://www.marxists.org/archive/marx/works/download/pdf/Manifesto.pdf, p. 26.
} 
freedom of thought on all matters, personal conviction, and commitment to a religion or belief. The Committee stressed that freedom of thought and conscience are essential and cannot be derogated from, even in times of public emergency. It is worth noting that according to article 4 (1) of the ICCPR, "In time of public emergency which threatens the life of the nation and the existence of which is officially proclaimed, the States Parties to the present Covenant may take measures derogating from their obligations under the present Covenant [...]." Thus, even a threat to the existence of a nation, and therefore in certain cases democratic society, cannot constitute an argument for taking away the freedom of thought, conscience and religion.

The restriction imposed on state power has a profound ontological justification for both the individual (human) as well as democratic society. As emphasized above, freedom of thought, conscience and religion is inscribed in the essence of the individual (human) and in the existence of the individual within the political and legal order. Thus, the existence of an individual (human) is tantamount to the existence of a subject enjoying the freedom of thought, conscience and religion. An act directed against these freedoms should therefore be regarded as an act directed against a human, and this is because of the fact he is human.

By analogy, the essence of democratic society, a sine qua non for its existence, is pluralism, which is not possible without actual freedom of thought, conscience and religion of members of society. Thus, the restriction of freedoms to save a democratic society is an intrinsically contradictory act - comparable to the act of suicide committed by an individual in order to save its life in the event of a threat.

It is obvious that the interpretation of the freedom of thought, conscience and religion presented above, in its absolute character, could in itself constitute a threat to what comprises a democratic state ruled by law. If it is natural for an individual to make moral judgments based on autonomously chosen or even created criteria, and then the individual acts in accordance with them, then it may turn out that she negates the existence of analogous freedoms on the part of others and tries to impose on them her vision of what is good and bad. Thus in some situations these freedoms can and even must be limited.

The quoted above article 18 (1) of the ICCPR makes a clear distinction between the primary act - "freedom to have or to adopt a religion or belief of his choice" and the secondary act - "freedom, either individually or in community with others and in public or private, to manifest his religion or belief in worship, observance, practice and teaching." As a result, in legal education, two levels of freedom of thought, conscience and religion have 
been distinguished: internal (forum internum) and external (forum externum) freedoms (Janyga 2004).

The forum internum, in accordance with article 18 (2) of the ICCPR, cannot be subjected to any limit. The individual possesses full, unlimited rights to autonomy of thought, conscience and religion. It is always up to the individual to answer the questions: How should I live? What is my overriding value? What model of life do I wish to pursue? etc.

External freedom, the freedom to act according to one's own convictions - the departure of the individual from the interior castle - must consider the realities of democratic society, and particularly its value system. In the external sphere, the freedom of thought, conscience and religion, as mentioned above, may, and in some cases must, be limited if hypertrophy and paralysis of the state are to be avoided. In the context of further deliberations, I will focus on the Holy Grail of the individual and the democratic state ruled by law - the forum internum.

Finally, it is worth emphasizing that the unique rank and importance both for individuals as well as the democratic state ruled by law - of the freedom of thought, conscience and religion has also been underlined in the human rights system of the Council of Europe, particularly in the treaty that is the culmination, or rather the foundation, of this system, i.e. the Convention for the Protection of Human Rights and Fundamental Freedoms of 1950. Article 9 (1) of that Treaty states: "Everyone has the right to freedom of thought, conscience and religion," while the European Court of Human Rights added: "as enshrined in Article 9 (art. 9), freedom of thought, conscience and religion is one of the foundations of a 'democratic society' within the meaning of the Convention. [...] The pluralism indissociable from a democratic society, which has been dearly won over the centuries, depends on it" (Kokkinakis v. Greece, para 31).

\section{WHAT ABOUT NEUROSCIENCE AND NEW HUMAN RIGHTS?}

Problems related to the functioning of the human brain and mind have preoccupied the minds of scientists for centuries. However, for centuries biological investigations had been limited to describing a dead organ harvested from a corpse, sometimes alive in the case of animal samples. Modern imaging techniques have enabled viewing the living human brain while it is working. Moreover, not only can we see how the brain works (which is particularly useful for diagnostics), we can also directly affect it using pharma- 
ceuticals, electric or magnetic field stimulation. The prospect of using neuronal stem cells for this purpose has been emerging. NBIC convergence, especially the introduction of modern technologies into the sphere of neuroscience, is slowly paving the way for neural engineering. Evidence of this is hard economic data: in 2006 the value of the global market for neurodevices used for medical purposes ranged between $\$ 2.3$ and \$3.4 billion (Making Perfect Life..., para 4.2.2.), and it is estimated to reach $\$ 11.61$ billion in 2021 (Est, Stemerding, Rerimassie, Schuijff, Timmer, Brom, p. 17). It should be noted that apart from the market for medical devices, there is a market for nonmedical devices that - and this cannot be ruled out - perhaps already is on the verge of explosion.

The doubts and problems associated with widespread use of such devices, particularly threats to individuals in the context of freedoms and rights, have been described in detail by M. Ienca and R. Andorno in the article referred to above, and I will therefore not present them here. The answer to these threats is the new human rights:

1. the right to mental privacy;

2. the right to mental integrity;

3 . the right to psychological continuity.

It is hard to disagree that these rights are a response to progress in the neuroscience field. Moreover, prima facie, they seem to properly balance the interests of individuals and society, protecting the former from possible unwanted consequences of using neurotechnology, while simultaneously enabling scientific, technological, and even civilizational development. What is of particular importance is the fact that Ienca and Andorno adopted the perspective of the individual - the individual understood not as an abstract idea but as a particular person making decisions about themselves. Referring to the proposal of Bublitz (Bublitz 2013), Ienca and Andorno indicate that cognitive liberty is "often also referred to as mental self-determination, comprises two fundamental and intimately related principles: (a) the right of individuals to use emerging neurotechnologies; (b) the protection of individuals from the coercive and unconsented use of such technologies. As he concisely put it, cognitive liberty is the principle that guarantees «the right to alter one's mental states with the help of neurotools as well as to refuse to do so»" (Ienca, Andorno 2017, p. 10). Developing their argument, Ineca and Andorno point out that such cognitive liberty is a conditio sine qua non of any other freedom. "Cognitive liberty, therefore, is necessary to all other liberties, because it is their neuro-cognitive substrate. As such, cognitive liberty resembles the notion of 'freedom of thought' which is usually considered the essential 
justification of other freedoms such as freedom of choice, freedom of speech, freedom of press, and freedom of religion" (Ienca, Andorno 2017, p. 10).

Fully agreeing with the justification for the need to guarantee cognitive liberty, in particular its importance to the individual, I must express some doubt as to its scope. Cognitive liberty, presented in this way, basically leaves the decision on the use of neurotechnology in the hands of the individual. At first glance, this approach seems to be embedded in the "libertarian" nature of the human rights philosophy. Every individual has the right to decide for himself, to make choices that affect his perception of reality and functioning in the world, as long as it - simply put - does not violate the rights and freedoms of others or legitimate public interest. Naturally, this freedom includes the possibility of using neurotechnology. In essence, similarly to using over-the-counter drugs or dietary supplements, the individual should be provided with access to information on possible, including undesirable, consequences of using particular neurodevices and then - in accordance with the volenti non fit iniuria principle - the individual would be able to use them freely. Obviously, there would still be the issue of safeguarding the individual against undesirable behaviors or actions of third parties. However, these problems would be perfectly solved by the new human rights and legal instruments proposed by Ienca and Andorno.

Since the "image" seems coherent and is built on a relatively easily identifiable and seemingly acceptable axiology, what is the problem? The problem is with the nature of freedom, as it is understood under the current philosophy of human rights. As indicated above, freedom of the individual is divided into two areas: forum internum and forum externum. Thus far, the forum internum has remained essentially closed to the outside world in terms of direct influence on its mental structures. With the help of neurotechnology, we are opening the gates of our interior castle. As a result, there is considerable doubt as to whether this opening can be reconciled with the deepest essence of freedom, even if it is completely dependent on the decision of the individual concerned? Doesn't it in a sense negate this freedom? In a sense, we have a variation of the question about the extent of the rights of a majority in a democratic society; in other words, can a democratic society that recognizes the ideals of the rule of law democratically renounce freedom? Can an individual freely allow interference into the sphere of their interior castle (forum internum) to third parties, leading to a modification of the essence of that freedom? In other words, does the freedom of the individual in a democratic state ruled by law also include the decision to renounce that freedom? 
While within the philosophy of morality, there is the possibility of giving a positive response to the above questions, or even to perceive in this act the highest manifestation of freedom, this possibility seems to disappear within the context of the philosophy of human rights. To provide a positive reply to the above question would lead to the conclusion that either the state is a priori exempted from the obligation to protect human freedoms within the forum internum, or because of an individual's decision, the protection of this sphere of freedom may be weakened to some extent. Given the importance of this freedom, both to the individual and to the democratic state ruled by law, it seems that the above possibilities should be rejected. We should remember that the analyzed value captures the essence of the individual from the point of view of the principle of a democratic state ruled by law and is a necessary condition for the existence of a democratic state rule by law - it is one of the most vital elements. Consequently, an unconditional obligation to safeguard the freedom of thought, conscience and religion in its forum internum dimension is the state's responsibility.

By analogy, it can be said that the question of the state's possibility to withdraw from protecting the forum internum resembles, to some extent, the question of the possibility of waiving or lowering the level of protection of an individual's life in view of their decision. We should remember that this question was raised in particularly dramatic circumstances in front of the European Court of Human Rights by Diane Pretty fifteen years ago. Diane Pretty suffered "from motor neuron disease (MND). This is a progressive neurodegenerative disease of motor cells within the central nervous system. The disease is associated with progressive muscle weakness affecting the voluntary muscles of the body. As a result of the progression of the disease, severe weakness of the arms and legs and the muscles involved in the control of breathing are affected. Death usually occurs as a result of weakness of the breathing muscles, in association with weakness of the muscles controlling speaking and swallowing, leading to respiratory failure and pneumonia. No treatment can prevent the progression of the disease" (Pretty v. The United Kingdom, para 7).

Fearing the inevitable approach of the end, full of suffering and indignity, Pretty, unable to commit suicide due to physical limitations, demanded her husband be granted immunity from prosecution if he assisted her in committing suicide. In accordance with British law "it is however a crime to assist another to commit suicide (section 2(1) of the Suicide Act 1961)" (Pretty v. The United Kingdom, para 9). 
Pretty argued that art. 2 of the European Convention on Human Rights (Everyone's right to life shall be protected by law...) "protected not only the right to life but also the right to choose whether or not to go on living. It protected the right to life and not life itself, while the sentence concerning deprivation of life was directed towards protecting individuals from third parties, namely the State and public authorities, not from themselves. Article 2 , therefore, acknowledged that it was for the individual to choose whether or not to go on living and protected her right to die to avoid inevitable suffering and indignity as the corollary of the right to life" (Pretty v. The United Kingdom, para 35).

The European Court of Human Rights did not agree with Pretty stating that "article 2 cannot, without a distortion of language, be interpreted as conferring the diametrically opposite right, namely a right to die; nor can it create a right to self-determination in the sense of conferring on an individual the entitlement to choose death rather than life" (Pretty v. The United Kingdom, para 39).

It seems we are dealing with the same situation in the case of the possibility of "allowing" the outside world to interfere with freedom of thought, conscience and religion in its forum internum dimension. The possibility of allowing third parties to directly interfere in this sphere (outside of medical interventions, naturally) cannot be derived from the essence of the right to freedom of thought, conscience and religion in its forum internum dimension. On the contrary, the purpose of this law is to safeguard the individual from such interference and, as it appears, the democratic state ruled by law does not possess the ability to cede its duties to a free individual or even reduce them.

Naturally, at this point, it can be argued that life and freedom are completely different values, and thus it is impossible to simply extrapolate conclusions about the right to life onto the right to freedom of thought, conscience and religion. Of course the differences are significant, but again largely within the philosophy of morality rather than the philosophy of human rights. We should remember that the life of an individual, as well as her freedom from the point of view of human rights philosophy, is an existing value to which the state answers. The biological phenomenon, the representative of Homo sapiens, equates to the axiological and normative phenomena of the free individual. Essentially, these phenomena are related and cannot be separated without violating the anthropology of human rights as well as the essence of the democratic state ruled by law. 


\section{CONCLUSION - BIOLAW AND "THE DEATH OF GOD"}

The purpose of the above argument was to identify significant doubts concerning the possibility of reconciling new human rights with the philosophy of human rights, in particular the right to freedom of thought, conscience and religion. The new human rights, formulated by Androno and Ienca, perfectly fit into the external dimension of the right to freedom of thought, conscience and religion (forum externum), that is a space in which the individual exits into the world, revealing his thoughts, beliefs, and desires... The problem is that neurotechnology, in its essence, interferes with something else - namely the forum internum. It ruthlessly enters the interior castle of the individual, re-arranging it in a specific way. As a consequence, a dangerous imbalance to one of the pillars of human rights and a democratic state ruled by law occurs. While the individual herself has the full right to completely create and transform her interior castle, the outside world has no access to it. From the point of view of the democratic state ruled by law, even the decision of a free individual to open the gates of this fortress is irrelevant. The state is still obliged to guard these gates and no one can free it from this obligation.

What does this mean? Of course, there will be progress, as surely as the coming of the future, whether we want it or not. New technologies will increasingly and decisively enter our lives, also in the biological dimension. So what can we do? Ienca and Andorno presented one of the possibilities, proposing the redevelopment of the human rights system so that the basic interests of individuals are protected from the undesirable effects of progress. The problem with this is that the proposed redevelopment requires us to rethink the core elements of the human rights system, since it cannot be reconciled with its foundations. First of all, the human rights' concept of freedom must then be reconsidered. Can the right to freely shape the interior castle with the participation of other people be derived from the freedom of the individual? Can a state that is obliged to protect our fundamental rights and freedoms be released from its duties by the holder of these rights and freedoms? If so, shouldn't these values that within the human rights protection system are considered universal, objective, and related to the essence of the individual be regarded as relative, dependent on the individual's decision? And if so, what will be the foundation for this kind of decision - freedom that in essence ceases to be freedom? The next step will be the need to rethink and perhaps redefine human dignity. If the evolution of human rights systems moves towards self-determination of one's nature by free individuals, then the 
concept of human dignity, which is essentially based on certain axiological axioms on human nature, will become almost empty and thus devoid of meaning. If we acknowledge that nature is dependent on an individual's decision, and thus we recognize its plasticity and relativity, how can it be an argument for judgements to postulate universality (e.g.: judgments on the inherent nature of human freedom)?

Everything points to the fact that we are on the verge of a human rights' revolution. We have to answer the question of whether the idea of human rights, in its present $20^{\text {th }}$ century form, corresponds to the realities of the $21^{\text {st }}$ century. Does the vision of the human being, accepted by the creators of the Universal Declaration on Human Rights, the International Covenant on Civil and Political Rights... correspond with the image of a human as seen by modern science? And should we do something about it?

Friedrich Nietzsche in the famous $125^{\text {th }}$ aphorism of The Gay Science described the dramatic call of the Madman. Let's cite it in full:

Haven't you heard of that madman who in the bright morning lit a lantern and ran around the marketplace crying incessantly, 'I'm looking for God! I'm looking for God!' Since many of those who did not believe in God were standing around together just then, he caused great laughter. Has he been lost, then? asked one. Did he lose his way like a child? asked another. Or is he hiding? Is he afraid of us? Has he gone to sea? Emigrated? - Thus they shouted and laughed, one interrupting the other. The madman jumped into their midst and pierced them with his eyes. 'Where is God?' he cried; 'I' 11 tell you! We have killed him - you and I! We are all his murderers. But how did we do this? How were we able to drink up the sea? Who gave us the sponge to wipe away the entire horizon? What were we doing when we unchained this earth from its sun? Where is it moving to now? Where are we moving to? Away from all suns? Are we not continually falling? And backwards, side wards, forwards, in all directions? Is there still an up and a down? Aren't we straying as though through an in nite nothing? Isn't empty space breathing at us? Hasn't it got colder? Isn't night and more night coming again and again? Don't lanterns have to be lit in the morning? Do we still hear nothing of the noise of the grave-diggers who are burying God? Do we still smell nothing of the divine decomposition? - Gods, too, decompose! God is dead! God remains dead! And we have killed him! How can we console ourselves, the murderers of all murderers! The holiest and the mightiest thing the world has ever possessed has bled to death under our knives: who will wipe this blood from us? With what water could we clean ourselves? What festivals of atonement, what holy games will we have to 
invent for ourselves? Is the magnitude of this deed not too great for us? Do we not ourselves have to become gods merely to appear worthy of it? There was never a greater deed - and whoever is born after us will on account of this deed belong to a higher history than all history up to now!' Here the madman fell silent and looked again at his listeners; they too were silent and looked at him disconcertedly. Finally he threw his lantern on the ground so that it broke into pieces and went out. 'I come too early', he then said; 'my time is not yet. This tremendous event is still on its way, wandering; it has not yet reached the ears of men. Lightning and thunder need time; the light of the stars needs time; deeds need time, even after they are done, in order to be seen and heard. This deed is still more remote to them than the remotest stars - and yet they have done it themselves!' It is still recounted how on the same day the madman forced his way into several churches and there started singing his requiem aeternam deo. O Led out and called to account, he is said always to have replied nothing but, "What then are these churches now if not the tombs and sepulchres of God?' (Nietzsche 2007, p. 119-120).

Perhaps we are in a similar situation? Our God has died. What was the basis of human rights systems, the specific vision of a human being, and the values attributed to it, has died and become empty, and we, for fear of admitting to what we have done, pretend to ourselves that nothing has changed. But if that is the case, then do we know on what values we should build the system of norms? What are its basic rules, and what is their content? What is hidden behind the facade of the words from which we constitute laws? And are we sure we really want that?

\section{REFERENCES}

IENCA, MARCELlo, ANDORno, Robero. Towards new human rights in the age of neuroscience and neurotechnology. Life Sciences, Society and Policy 2017, 5(13). doi: 10.1186/s40504017-0050-1.

Roco, Mihail C., Bainbridge, William S. Converging Technologies for Improving Human Performance. Nanotechnology, Biotechnology, Information Technology and Cognitive Science. Dordrecht: Kluwer Academic Publishers, 2003.

Bainbridge, William S., Roco, MihaIL C. Managing Nano-Bio-Info-Cogno Innovations: Converging Technologies in Society. Dordrecht: Springer, 2005.

Descartes, René. The Philosophical Writings of Descartes. Cambridge: Cambridge University Press, 1985.

Est, Rinie, Stemerding, Dirk, Rerimassie, Virgil, SchuijfF, Mirjam, Timmer, Jelte, BROM Frans. From bio to NBIC - From medical practice to daily life Report written for the Council of Europe, Committee on Bioethics. Hague: Rathenau Instituut, 2014. 
JANYGA, WoJCIECH. Wolność sumienia i wyznania wobec wyzwań pluralizmu religijnego [Freedom of consientious and religion faceing the religious pluralism]. Państwo i Prawo [Law and State] 2004, 10.

KoKKINAKIS V. GREECE, ECtHR 1993, Application no. 14307/88.

Making Perfect Life, European Governance Challenges in $21^{\text {st }}$ Century Bio-engineering, Final Report, PE 471.574.

NAWROT, OKTAWIAN. Conscientious objection versus human rights and their philosophy. Polish Law Review 2015, 1:11-34. doi: 10.5604/24509841. 1197117.

NiETZSChe, Friedrich. The Gay Science. Cambridge: Cambridge University Press, 2007.

Pretty v. The United Kingdom, ECtHR 2002, Application no. 2346/02.

ZDYBICKA, ZOFIA J. Wolność religijna fundamentem ludzkiej wolności [Freedom of religion as a fundament of human liberty]. Człowiek $w$ kulturze [Man in the culture] 1998, 11.

\author{
CO Z WEWNĘTRZNĄ TWIERDZĄ? \\ ODPOWIEDŹ NA PROPOZYCJE IENCA I ANDORNO DOTYCZACA NOWYCH PRAW \\ CZŁOWIEKA W ERZE NEURONAUKI I NEUROTECHNOLOGII
}

\author{
S t r e s z c z e n i e
}

Zaproponowane przez Ineca i Andorno, w artykule „Towards new human rights in the age of neuroscience and neurotechnology", trzy nowe prawa człowieka na pierwszy rzut oka wydają się niezwykle atrakcyjną odpowiedzią na rosnące ze strony neuronauki zagrożenia dla ludzkiej wolności. Jednakże ich głębsza analiza, zwłaszcza w kontekście zasad systemu ochrony praw człowieka Rady Europy, wraz z jego kamieniem węgielnym - przyrodzoną ludzką godnością, ujawnia szereg poważnych wątpliwości. Najpoważniejsza z nich dotyczy możliwości pogodzenia stojącej u podstaw neuronauki i neurotechnologii filozofii, wraz z milcząco przyjmowaną w ramach niej wizją człowieka, z filozofią praw człowieka i jej antropologią. Druga, bardziej szczegółowa, lecz równie istotna z punktu widzenia systemu wartości demokratycznego państwa prawnego, wątpliwość dotyczy kwestii pogodzenia nieterapeutycznych ingerencji w ,wewnętrzną twierdzę" jednostki - mózg wraz z nadbudowanym nad nim umysłem - z obowiązkiem poszanowania i zabezpieczenia przez państwo prawa do wolności myśli, sumienia i religii, rozumianego zarówno jako fundamentalne prawo człowieka, jak i konstytutywny element systemu wartości demokratycznego państwa prawnego.

Słowa kluczowe: cognitive liberty (odpowiednikiem w języku polskim byłoby: prawo do mentalnej auto-determinacji); wolność myśli; wolność sumienia; neuronauka; filozofia praw człowieka. 